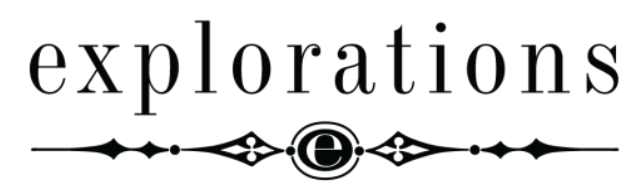

Explorations: A Journal of Language and Literature

\title{
REVIEW
}

\section{Somaly Mam. 2008. The Road of Lost Innocence: The True Story of a Cambodian Heroine. New York: Spiegel and Grau.}

\author{
DOI: $10.25167 / \mathrm{EXP} 13.20 .8 .10$
}

U. H. Ruhina Jesmin (Khulna University, Bangladesh)

ORCID: 0000-0002-3988-3811

Somaly Mam's 2008 memoir, The Road of Lost Innocence: The True Story of a Cambodian Heroine, bears witness to intersectional axes of socio-economic, cultural, and political power relations behind violence against women (VAW) and sex trafficking in Cambodia. The book calls for human rights activism on prevention and response to VAW and sex trafficking. The book recounts Mam's first-hand experience as a sex slave. It is an essential book on sex trafficking in Cambodia and is significant as it is a global health concern and a human rights issue.

Mam escaped sexual slavery and involved in human rights activism and now campaigns against sex-trafficking. Her story is definitely a story of power relationships of dominance and subjugation. Her ethnicity, social status, and gender constitute an interlocking system of violence against her. Political aggression gave rise to displaced aggression on poor minority. Violence rates against poor sex slaves were higher than women of higher status and high-income. A war-torn country, like Cambodia, creates economic and political crises and patriarchal state policies perpetuate VAW. An intersection of oppression cannot be denied. Politically tolerated sex trade intersects with VAW. Cambodia had a turbulent history due to Khmer Rouge from 1975-1979. The oppressive regime caused severe food crises in 1979. Poverty, lack of education and employment, and lack of healthcare made people, especially women and children of minority groups, vulnerable to an unimaginable extent. Sex work was an economic alternative to women of poor groups.

Mam, born around 1970 at Bou Sra village during Cambordia's genocidal civil war, belonged to a Phnong Buddist ethnic minority at the countryside in Northeastern Cambodia. Her parents left her when she was still a small child in 1970. There is an interlinking point between her personal experience and larger socio-political upheavals, such as American bombing of Cambodia at the end of the Vietnam War and terrible years of Khmer Rouge regime. Mam's biological parents were an old tribe of mountain people who were lower in social class than the mainstream Khmer people dominating the lowlands of Cambodia. It shows a matrix of domination from larger political to social and then to personal levels.

Explorations: A Journal of Language and Literature, 8 (2020), pp. 113-115 
The book uncovers patriarchal hegemony and domestic/sexual slavery as mutually constitutive intersections which perpetuate inequitable power relations in a society. Sexual slavery finds suitability as well as tolerability in the context of patriarchal hegemonic society. Mam was caught between patriarchal hegemony and sexual slavery. A Cham Muslim man temporarily gave little Mam shelter and one day he sold her to a stranger, "Grandfather". The political crises ran parallel with her intersectional experiences. She was forced to do household chores for grandfather's home and for other families to earn money. He sexually abused her and sent her to a Chinese merchant in compensation for his own debts. The grandfather sold her into an abusive marriage with a soldier fighting the Khmer Rouge. Her husband used to beat her often with the butt of his military rifle on her back. Mam realized that she only exchanged one master for another and that she was destined to serve her masters. She came to realize it clearly when the grandfather sold her (at the age of sixteen) into Aunty Nop's brothel in 1986 and then into Aunty Peuve at Phnom Penh.

The book shows a correlation between state policies and VAW. The rate of VAW in Cambodia was alarmingly high. The rate had been accelerated by the inclusion and implementation of state-tolerated policy against women. Mam talks about Chbap Srey which officially and powerfully legitimized patriarchal hegemony as well as VAW. Chbap Srey, a written state policy/a strict code of conduct for Cambodian maidens, was a mandatory part of the school curriculum. Besides, failure of law enforcement agencies, legislators, and policy makers to protect women and sex workers from violence could certainly be ascribed to an implicit acceptance of VAW in society.

Women as sex slave and sex trafficking were frighteningly ordinary in Cambodia. Three decades of bombing, genocide, and starvation led the country into a state of moral bankruptcy. Aftermath of Khmer Rouge Regime, people no longer cared about anything except money. Sex business played a crucial role in the economy of Cambodia and gained a political currency. Mam asserted that it was a huge global business as lucrative as drugs. Sex trafficking is actually an outcome of sex business. As such, they share an intersectional power relation as regards economic alternative and power. Involvements of law enforcement agencies in sex business, criminality of police officers, law-breaking of judges regarding civil rights triggered the human rights crises and made the issue politicized.

Constant demand for sex workers under a state-tolerated sex business intersects with sex trafficking. This is because sex trafficking is the process that delivers victims into sex trade. Mam's memoir reveals shocking details of healthcare of sex workers in brothels of Phnom Penh. Unhygienic accommodation of brothels, filthy bodies of customers, STD and AIDS-ridden customers, sewed-up virgins as well as untreated sex workers leading to death laid bare medically undesirable condition and human rights violation. The brothels sold children who were "bonafide virgins" of five/six years old. Sex workers were chained, beaten with electric cables and some were shot dead. Sometimes, they were untreated and thrown to the streets to die like dogs. Due to socio-cultural barriers, girls in sex trade were never welcomed at their homes. Sex workers' social exclusion intertwined with human rights violation increased the rate of their vulnerability to violence and STD, HIV health risks. During Khmer Rouge regime, healthcare came to a halt.

State-tolerated sex business along with human rights violation intersects with political power relations as they use power to bias the legal system for their own benefits. Since VAW is embedded within a complicated web of institutionalized patriarchal hegemony, 
the issues get the dimension of political power dynamics. Mam's writing effectively questions the power relations which have a devastating impact particularly on healthcare of sex slaves.

This work is licensed under the Creative Commons Attribution 3.0 Unported License. http://creativecommons.org/licenses/by/3.0/

AUTHOR'S BIO: U. H. Ruhina Jesmin, $\mathrm{PhD}$, is an Associate Professor at English Discipline, Khulna University, Bangladesh. Her scholarly research articles "Narcissistic Personality in Arthur Miller's Death of a Salesman and Saul Bellow's Seize the Day: a Comparative Study" (2018) and "Cultural and Political Paradigms of FGM: An Intersection of Race and Sex in Alice Walker's Possessing the Secret of Joy" (2019) were published by Daugavpils University and University of Suceava respectively. Her research fields include African American literature and gender and sexuality studies. Her research mostly focuses on Alice Walker's novels and on the intersections of race, sex, and sexuality.

E-MAIL: ruhina@ku.ac.bd 